\title{
Ecological Footprints for Aquaculture Possibility in Selected Mangrove Regions of Jaffna, Sri Lanka
}

\author{
S. Saruga*, K. Sivas hanthini., S. Suthars hiny, K. Gunaalan and P. Shobiya \\ Department of Fisheries, Faculty of Science, University of Jaffna, Sri Lanka. \\ *Email: sarugasiva@gmail.com
}

\begin{abstract}
The present study was carried out to analyze the possibility of practicing aquaculture in selected mangrove regions in Jaffna, Sri Lanka. A detailed study on the possibility of undertaking aquaculture has been carried out in Sarasaalai and Kapputhu mangrove regions. The water quality parameters were measured, organic matter was estimated and available fish species were collected and identified during the study period. Samples were collected in the second week of each month from June 2016 to November 2016. Water quality parameters such as water temperature, salinity, $\mathrm{pH}$, dis solved oxy gen, water depth and turbidity were measured. Organic matter was estimated for soil samples collected from the study areas. Water quality parameters were analyzed by two sample t-test using minitab13. Identification of all collected fish species were confirmed according to the standard literature by observing their morphological and meristic characters. Statistical analysis shows no significant difference between Sarasaalai and Kapputhu in water temperature $(\mathrm{P}=0.062)$, salinity $(\mathrm{P}=0.402)$, dissolved oxygen $(P=0.773), \mathrm{pH}(\mathrm{P}=0.262)$ and water depth $(\mathrm{P}=0.798)$. Significant difference $(\mathrm{P}=0.001)$ was observed for turbidity in both locations. High percentage of organic matter was observed in Sarasaalai. The identified fish species in both locations were Chanos chanos, Platycephalus fuscus, Oreochromis mossambicus, Nematalosa nasus, Hyporhamphus limbatus, Hemiramphus marginatus, Etroplus maculatus, Gerres abbreviatus and Gerres oyena. The most abundant species found in Saras aalai was O. mossambicus and in Kapputhu were O. mossambicus, C. chanos, G. abbreviatus and G. oyena. The present investigation inferred that the specified species can be cultured in the said regions. However, a long term study on seed resources, environmental and climatic conditions of particular site would en sure more details on culture aspects of these species.
\end{abstract}

Keywords- Aquaculture, C. chanos, G. abbreviatus, Mangrove, O. mossambicus

\section{INTRODUCTION}

Fisheries in Sri Lanka contributes about $1.3 \%$ to the GDP (CBSL, 2016), with fish and fishery products providing about $70 \%$ of the animal protein consumed in the country. Aquaculture is still in its infant stage and is limited to coastal shrimp culture and the production of fish seed for stocking; farming of food fish in seasonal tanks and ornamental fish for export are other coastal activities. Mangroves are intertidal forested wetlands confined to the tropical and subtropical regions. In Sri Lanka, mangrove forests are found scattered mainly along the north-western, north-eastern and eastem coasts bordering lagoons and riverine estuaries.

In the present study two locations were chosen because there are intense mangroves in those regions and no studies were performed, yet. The present study was carried out to analyze the possibility of undertaking aquaculture practice in those selected mangroveregions in Jaffna, Sri Lanka.

\section{Materials AND Methodology}

\section{A. Studyarea}

The Sarasaalai mangrove region is located in the longitude of $80^{\circ} 10.262$ 'and latitude of $09^{\circ} 41.147^{\prime} \mathrm{N}$. Kapputhu mangrove region is located in the longitude of $80^{\circ} 10.782^{\prime} \mathrm{E}$ and latitude of $09^{\circ} 44.017^{\prime} \mathrm{N}$ (Figure 1).

\section{B. Sample collection}

Samples were collected in the second week of each month (from June 2016 to November 2016). Water samples and soil samples were collected by using water sampler, and mud sampler, respectively. Random samples of fishes were collected fromfishermen oncea month.

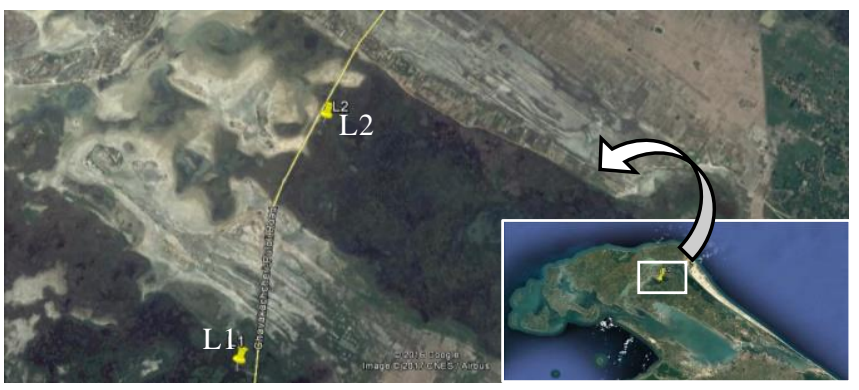

Figure 1: Sampling locations in Jaffna Peninsula: Sarasaalai (L1) and Kapputhu (L2) (Source: Google Earth)

\section{Sample analysis}

SmarTROLL handheld multi parameter was dipped into the water and water quality parameters such as water temperature, salinity, $\mathrm{pH}$ and dissolved oxygen were recorded. The depth of the water body was measured by meter rod. Turbidity meter was used to measure the turbidity.

The collected mud samples were kept in Hot Air Sterilizer and allowed to dry in $104^{\circ} \mathrm{C}$ for 5 hours. The crucible was weighed 
using electronic balance. A $5 \mathrm{~g}$ of dried mud s ample was added in the crucible and total (crucible +mud sample) weight was measured. The crucible was incinerated at $600^{\circ} \mathrm{C}$ for 5 hours in muffle furnace. Then crucible and sample weight was measured, from that weight loss (amount of organic matter) was calculated.

\section{Fish species identification}

All fish species were brought to laboratory and identification of all collected fish species were confirmed according to the standard literature (Munro, 1995) by observing their morphological and meris tic characters.

\section{STATISTICAL ANALYSIS}

Water quality parameters were analyzed by two sample t-test using minitab13. Differences were declared statistically significant at $p<0.05$, where significant differences were detected, the means were separated by the least significant difference (LSD) - Turkey test at 5\% probability level.

\section{RESULTS AND DisCUSSION}

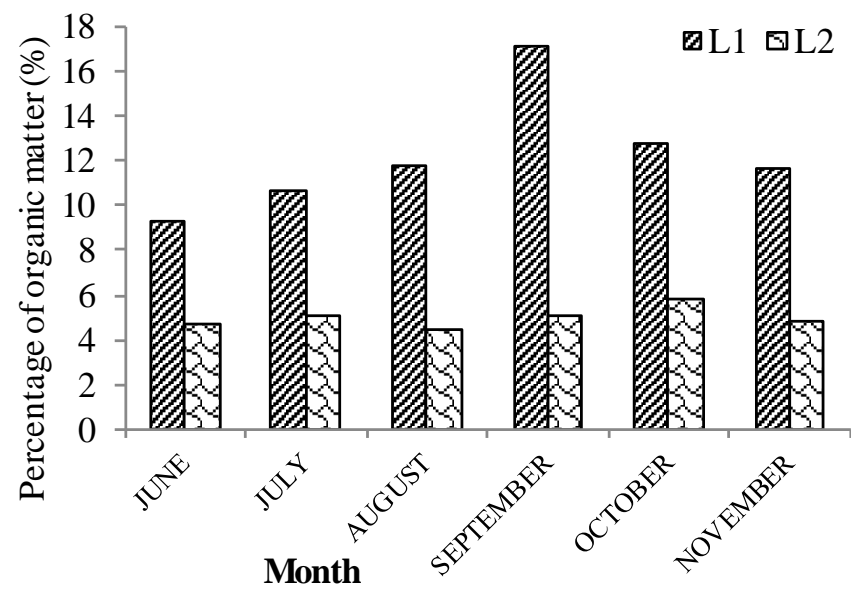

Figure 2: Percentage of organic matter recorded in Sarasaalai (L1) and Kapputhu (L2)

Mangrove forest known to be a place that are highly productive source of an org anic matter that give an energy to support variety of estuarine and near shore life (Hasrizal et al., 2009).

High percentage of organic matter was observed in Saras aalai mangroves (Figure 2) throughout the study period, which might be due to periodic re-suspension of sediments. Highest percentage of organic matter was observed in the month of September 2016, which was $17.11 \%$.

There were no statistically significant differences between Sarasaalai and Kapputhu mangroves in water temperature $(\mathrm{p}=0.06)$, salinity $(\mathrm{p}=0.40)$, dis solved oxygen $(\mathrm{p}=0.77), \mathrm{pH}$ $(\mathrm{p}=0.262)$ and water depth $(\mathrm{p}=0.79)$. As stated above, water temperature, DO, salinity, $\mathrm{pH}$ and water depth are the most important water quality parameters which influence on the biodiversity of the particular ecosystem. Those parameters may be the determinant factors of the available fish species in both locations.

The salinity is a limiting factor in the distribution of living org anis ms and it changes because the dilution and evaporation act most likely on the fauna in the coastal ecosystem (Paramasivamand Kannan, 2005). Amount of oxygen that can be hold by water depends on the water temperature, the salinity and also the pressure.

There were statistically significant differences between Saras aalai and Kapputhu in turbidity, as determined by $2 t$-test ( $\mathrm{p}=0.001$ ) which may cause due to the presence of high organic matter in Sarasaalai mangrove region. For many mangrove areas, high turbidity is needed to protect juvenile fish from predators. Even though it can harm fish and other aquatic life by degrading spawning grounds, reducing food supplies and affect the gill function of certain species. This may affect the abundance of fis $h$ species.

In both locations same fish species were identified (Table 1; Figure 4) and most abundance fish species was Oreochromis mossambicus. This is highly tolerable species for most of the water quality parameter changes. However commercially valuable species such as Chanos chanos and Gerres abbreviatus were abundantly found in Kapputhu.

It can be recommended that both mangrove regions are suitable for tidal aquaculture practices because it provides a relatively cheap way of tapping a rich resource. No fertilizers need to be added, as stocks of nutrients are carried by the water into the mangrove environment.

Table.1: Abundance of fish species (Total number of collected fish species from one gill net during 1 hour fishing time (throughout the survey)

\begin{tabular}{|c|c|c|c|}
\hline Identified species & $\begin{array}{c}\text { Common } \\
\text { name }\end{array}$ & $\begin{array}{l}\% \text { of fish } \\
\text { collected in } \\
\text { Sarasaalai }\end{array}$ & $\begin{array}{l}\% \text { of fish } \\
\text { collected in } \\
\text { Kapputhu }\end{array}$ \\
\hline Chanos chanos & Milk fish & $0.3 \%$ & $4.23 \%$ \\
\hline $\begin{array}{l}\text { Platycephalus } \\
\text { fuscus }\end{array}$ & $\begin{array}{l}\text { Dusky } \\
\text { flathead }\end{array}$ & $8.54 \%$ & $1.46 \%$ \\
\hline Nematalosa nasus & $\begin{array}{l}\text { Long-ray } \\
\text { bony bream }\end{array}$ & $6.4 \%$ & $2.54 \%$ \\
\hline $\begin{array}{l}\text { Oreochromis } \\
\text { mossambicus }\end{array}$ & Tilapia & $64.0 \%$ & $52.25 \%$ \\
\hline $\begin{array}{l}\text { Hyporhamphus } \\
\text { limbatus }\end{array}$ & $\begin{array}{l}\text { Congaturi } \\
\text { halfbeak }\end{array}$ & $5.19 \%$ & $2.82 \%$ \\
\hline $\begin{array}{l}\text { Hemiramphus } \\
\text { marginatus }\end{array}$ & $\begin{array}{l}\text { Barred } \\
\text { half-beak }\end{array}$ & $6.09 \%$ & $3.67 \%$ \\
\hline $\begin{array}{l}\text { Etroplus } \\
\text { maculatus }\end{array}$ & $\begin{array}{l}\text { Spotted } \\
\text { etroplus }\end{array}$ & $7.34 \%$ & $1.12 \%$ \\
\hline $\begin{array}{l}\text { Gerres } \\
\text { abbreviatus }\end{array}$ & $\begin{array}{l}\text { Blue- } \\
\text { blacked } \\
\text { silver biddy }\end{array}$ & $1.22 \%$ & $18.36 \%$ \\
\hline Gerres oyena & $\begin{array}{l}\text { Lined } \\
\text { silver- } \\
\text { biddy }\end{array}$ & $0.92 \%$ & $13.55 \%$ \\
\hline Total & & $100 \%$ & $100 \%$ \\
\hline
\end{tabular}



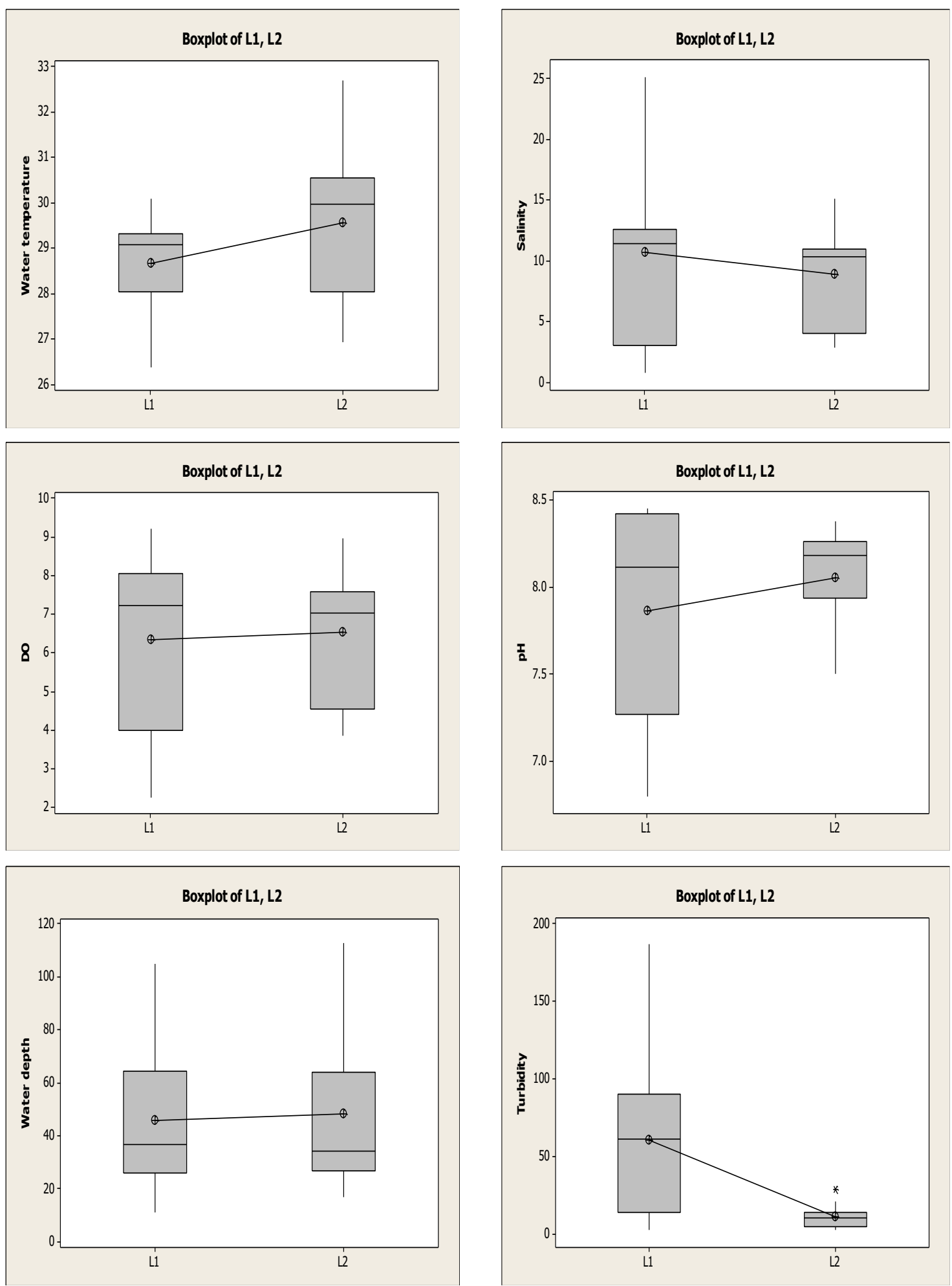

Figure 3: Box plot to show the homogeneity of L1 and L2 for water quality parameters 


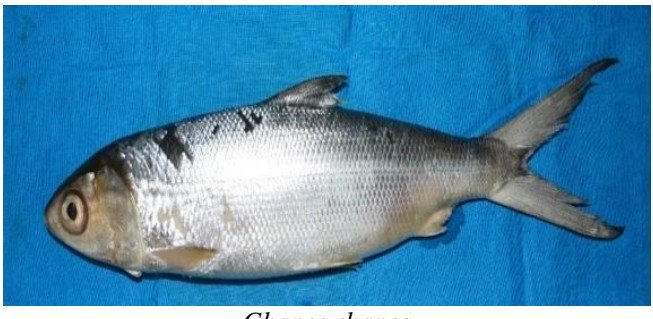

Chanos chanos

(Common name - Milk fish)

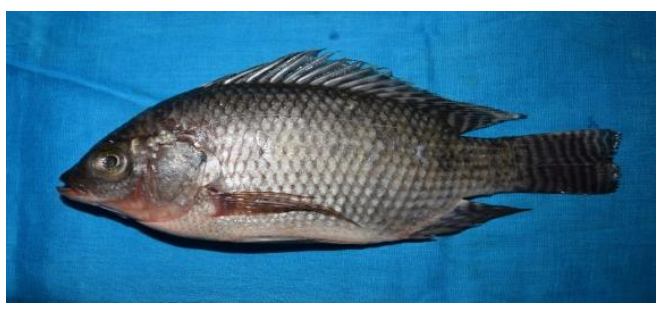

Oreochromis mosambicus

(Common name - Tilapia)

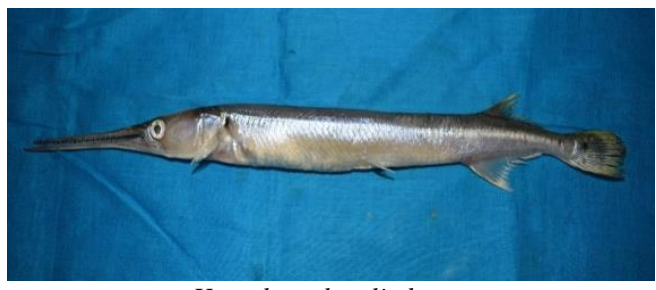

Hyporhamphus limbatus

(Common name - Congaturi halfbeak)

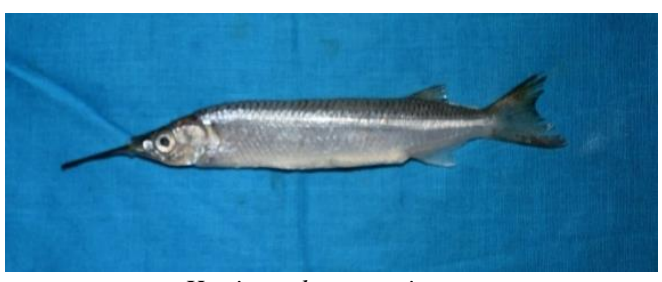

Hemiramphus marginatus

(Common name - Barred half-beak)

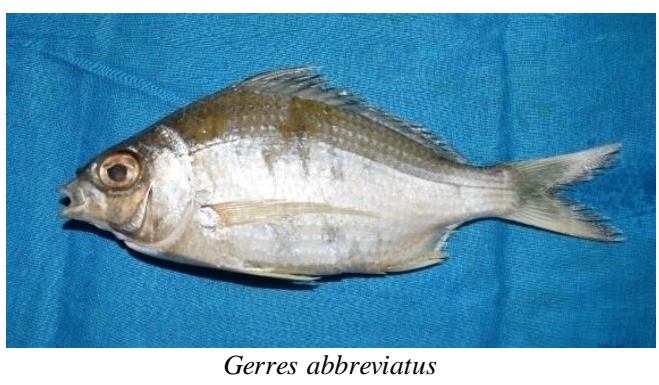

(Common name-Blue-blacked silver biddy)

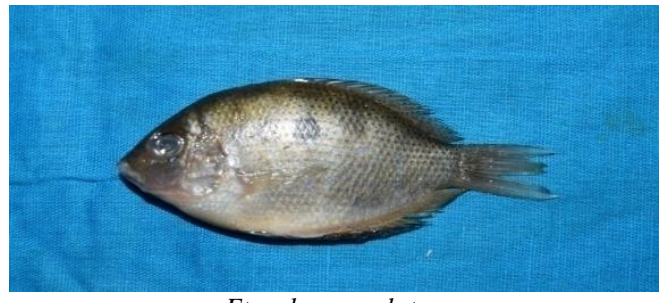

Etroplus maculatus

(Common name - Spotted etroplus)

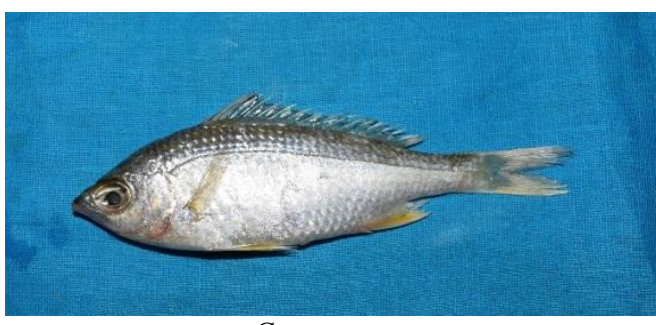

Gerres oyena

(Common name - Lined silver-biddy)

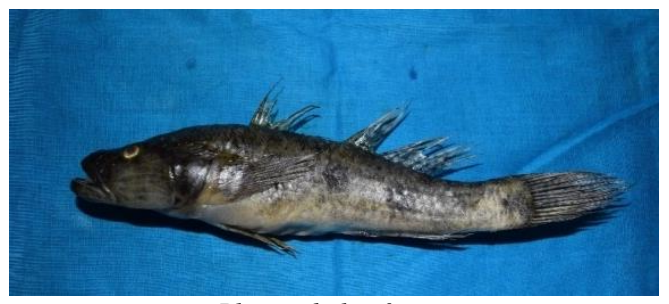

Platycephalus fuscus

(Common name - Dusky flathead)

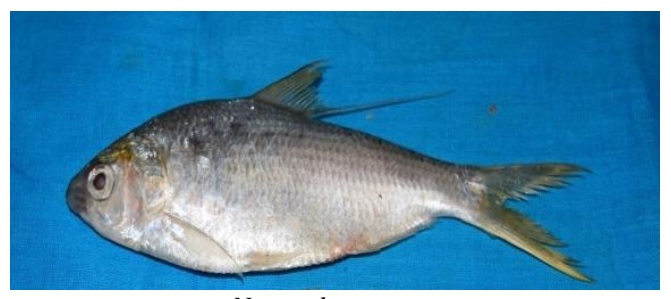

Nematalosa nasus

(Common name - Long-ray bony bream)

Figure 4: Identified fish species in Sarasaalai and Kapputhu mangrove waters 


\section{Conclusion}

This study provides the status of water quality conditions of mangrove environment, organic matter content of soil and available fish species. Water temperature, DO, salinity, $\mathrm{pH}$ water depth and turbidity were analyzed. There were statistically significant differences between Sarasaalai and Kapputhu in turbidity, as determined by $2 \mathrm{t}$-test ( $\mathrm{p}=0.001$ ). High percentage of organic matter was noticed in Sarasaalai mangrove water throughout the study period. The most abundance species in Sarasaalai was O. mossambicus and in Kapputhu were O. mossambicus, C. chanos, G. oyena and G. abbreviatus. The present study concluded that the identified dominant fish species can be cultured in the mangroveregions studied currently. However, a long term investigation on fish seed resources, environmental and climatic conditions of particular site would ensure more details on culture as pects of these species.

\section{References}

Has rizal, S., Kamaruzzaman, B.Y., Sakri, I., Ong, M.C. and Azhar, M.S.N., (2009). Seasonal distribution of organic carbon in the surface sediments of the Terengganu near shore coastal area.

Paramasivam, S. and Kannan, L., (2005). Physico-chemical characteristics of Muthupettai mangrove environment, Southeast coast of India. Int. J. Ecol. Environ. Sci, 31, pp.273278 .

Prabu, V. A., Rajkumar, M. and Perumal, P., (2008). Seasonal variations in physico-chemical characteristics of Pichavaram mangroves, southeastcoast of India. Journal of Environmental Biology, 29(6), pp.945-950.

Satheeshkumar, P. and Khan, A. B., (2012). Identification of mangrove water quality by multivariate statistical analysis methods in Pondicherry coast, India, Environmental monitoring and assessment, vol. 184, no. 6, pp.3761-3774.

Munro, S. R., (1955). Marine and Freshwater Fishes of Ceylon, Canberra, Dept. of External Affairs, pp. 1-351.

Dittmarand, T. S. and Lara, R. J., (2001). Driving forces behind nutrient and organic matter dynamics in a mangrove tidal creek in North Brazil, Estuarine, Coastal and diversity of a water body. Shelf Science, vol. 52, no. 2, pp.249-259. 
